\title{
Ikke kortisoninjeksjon mot tennisalbue
}

\section{Kortisoninjeksjoner og fysioterapi ved tennisalbue har dårlig lang- tidseffekt.}

Kortisoninjeksjon mot tennisalbue - lateral epikondylitt - gir ofte residiv, og positiv langtidseffekt er ikke dokumentert. En australsk forskergruppe har nylig undersøkt langtidseffekten av kortisoninjeksjon og

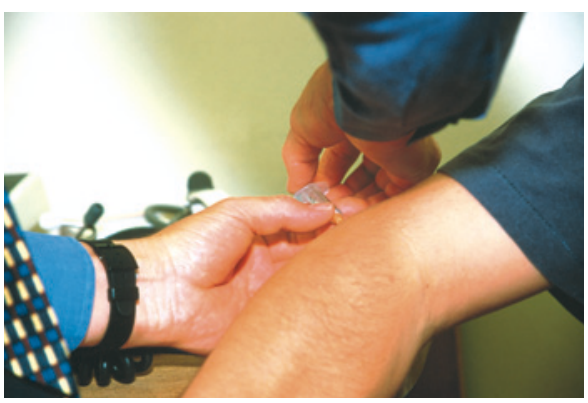

Illustrasjonsfoto Science Photo Library/NTB scanpix fysioterapi i kombinasjon (1). 165 pasienter ble randomisert i fire grupper. De fikk behandling med kortisoninjeksjon med eller uten fysioterapi eller placeboinjeksjon med eller uten fysioterapi.

Færre i kortisongruppen fikk stor eller fullstendig forbedring etter ett år enn i placebogruppen ( $83 \%$ mot $96 \%, \mathrm{p}=0,01)$, og de hadde langt oftere tilbakefall av tilstanden $(54 \%$ mot $12 \%, p<0,001)$. Tillegg av fysioterapi ga ingen endring i tilbakefallsrate eller plager etter ett år.

- Denne studien bekrefter at behandling av tendinopati med kortisoninjeksjoner er et tveegget sverd, sier professor Jan Magnus Bjordal i Forskergruppe i fysioterapi ved Institutt for global helse og samfunnsmedisin, Universitetet i Bergen.

- Som i tidligere metaanalyser rapporteres en positiv kortidseffekt - etter én måned er det sju ganger større sjanse for bedring med kortisoninjeksjon. Men studien viser også at kortisoninjeksjoner gir en signifikant negativ utvikling og flere tilbakefall enn placeboinjeksjon etter et halvt år og ett år, sier han.

- Et nytt moment er at studien viser at fysioterapi ikke har langtidseffekt hvis gitt den første måneden etter kortisoninjeksjon, mens individuelt tilpasset fysioterapi uten kortisoninjeksjon ga fire ganger større sjanse for forbedring etter en måned og en suksessrate på $89 \%$ etter et halvt år. Behandling av lateral epikondylitt bør derfor innbefatte en oppfordring til pasienten om tålmodighet, kombinert med tilpasset belastning og fysioterapi, sier Bjordal.

\section{Sigurd Høye}

sigurd.hoye@legeforeningen.no

Tidsskriftet

\section{Litteratur}

Coombes BK, Bisset L, Brooks P et al. Effect of corticosteroid injection, physiotherapy, or both on clinical outcomes in patients with unilateral lateral epicondylalgia: a randomized controlled trial. JAMA 2013; 309: 461-9

\section{Antiinflammatorisk behandling mot Alzheimers sykdom?}

\section{Mus med gener for Alzheimers sykdom er i noen grad beskyttet mot sykdomsutvikling hvis de mangler gener som fremmer inflammasjon.}

NLRP3-inflammasomet er et proteinkompleks som finnes i bl.a. makrofager og mikroglia. Det reagerer på ulike former for celleskade, bl.a. amyloid- $\beta$ og presenilin-1, som akkumuleres i hjernen ved Alzheimers sykdom. Disse proteinene finnes også hos eldre transgene APP/PS1-mus, en mye brukt musemodell for Alzheimers sykdom (1). Stimulert NLRP-3-inflammasom aktiverer caspase-1-enzymet, som danner interleukin 1. Dette cytokinet spiller en viktig rolle i utviklingen av inflammatoriske reaksjoner. I studien ble en rekke tegn på demens, bl.a. redusert stedshukommelse, mindre uttalt hos mus som manglet gener for produksjon av dette inflammasomet eller caspasen. Hos slike mus fant man flere mikroglia av renovatørtype enn av inflammasjonstype. Disse cellene fjernet amyloid- $\beta$ bedre enn mikroglia hos mus med intakt inflammasjonsreaksjon. Humant hjernevev fra pasienter med Alzheimers sykdom hadde også økt caspase-1-aktivitet.

- Resultatene fra denne studien er spen- nende og føyer seg inn i rekken av holdepunkter for at betennelsesprosesser kan spille en vesentlig rolle i utvikling og progrediering av Alzheimers demens, sier professor Torgeir Bruun Wyller ved Geriatrisk avdeling, Oslo universitetssykehus.

- Kanskje er det også nevroinflammasjon som gjør at delirium («akutt forvirring») øker risikoen for en akselerert demensutvikling. Patogenesen er antakelig mer sammensatt enn dette, og man skal være varsom med å tro at «den ene løsningen» er funnet. Hvorvidt antiinflammatorisk behandling mot demens blir en klinisk mulighet, gjenstår å se, avslutter Bruun Wyller

\section{Haakon B. Benestad}

h.b.benestad@medisin.uio.no

Universitetet i Oslo

\section{Litteratur}

1. Heneka MT, Kummer MP, Stutz A et al. NLRP3 is activated in Alzheimer's disease and contributes to pathology in APP/PS1 mice. Nature 2013; 493 674-8.
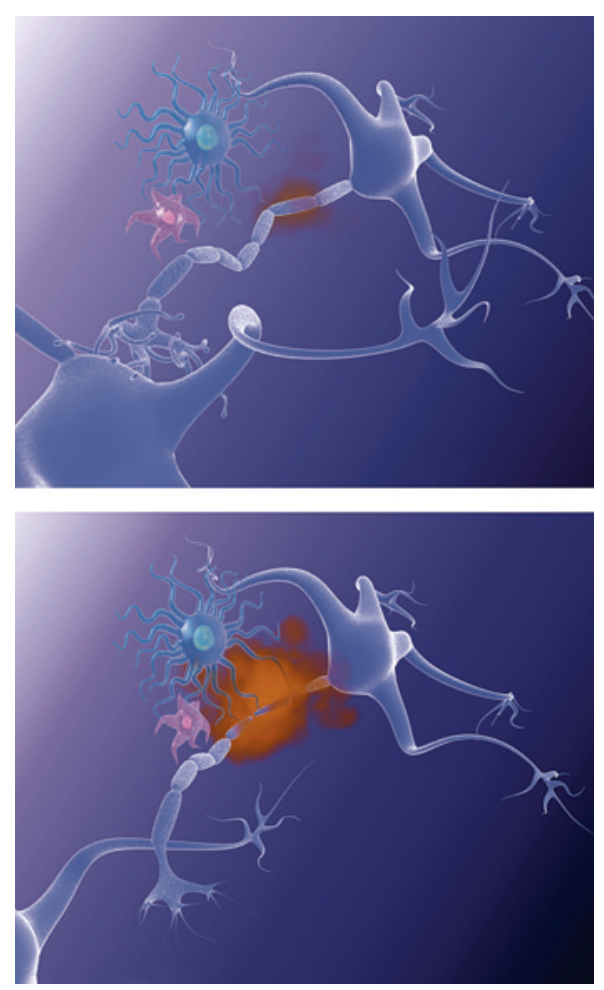

Science Photo Library/NTB scanpix 